\title{
Keadilan Spasial Dan Keseimbangan Kebutuhan Lokal Dalam Neo- Endogenous Model Pembangunan Pedesaan Di Desa Koto Mesjid, Kecamatan XIII Koto Kampar, Kabupaten Kampar
}

\author{
${ }^{1}$ Bunga Chintia Utami, ${ }^{2}$ Putri Asrina \\ ${ }^{123}$ Fakultas Ekonomi dan Bisnis, Universitas Riau, Indonesia
}

e-mail: bungachintiautami@lecturer.unri.ac.id

\begin{abstract}
Abstrak
Indeks pembangunan desa mengukur perkembangan kemandirian Desa berdasarkan implementasi terhadap Undang-Undang Desa. Kemandirin desa penting dilakukan untuk mendorong pembangunan. Hasil survey Potensi Desa (Podes) 2018 menunjukkan 87,43 persen desa di Riau adalah Desa Berkembang, 7,09 persen Desa Mandiri dan 5,48 persen adalah Desa tertinggal. Salah satu masalah dalam pembangunan desa adalah tidak sesuainya antara karakteristik dan potensi desa dengan kebijakan pembangunan yang dilakukan. Olehkarena itu perlu dilakukan identifikasi model pembangunan desa untuk dapat mengetahui kebijakan pembangunan yang tepat. Tujuan penelitian ini untuk melihat model neo-endogenous dalam pembangunan pedesaan di desa Koto Mesjid serta upaya pemerintah desa dalam membentuk karakteristik masyarakat dalam model neo-endogenous. Penelitian dilakukan pada desa Koto Mesjid Kabupaten Kampar dengan metode kualitatif diskriftif dan dibantu aplikasi nvivo plus 12 untuk memudahkan pengkodeaan dan menganalisis data kualitatif.
\end{abstract}

Keywords: Pembangunan, desa, neo endogenous.

\section{Abstract}

The rural development index measures the development of village independence based on the implementation of the rural regulations. Rural independence is important to encourage development. The results of the Rural Potential Survey (Potensi Desa /PODES) in 2018 that 87.43 percent of villages in Riau were Developing Villages, 7.09 percent of Independent Villages and 5.48 percent of underdeveloped villages. One of the problems in rural development is the mismatch between the characteristics and potential in the village and the development policies. Therefore, it is necessary to identify the rural development model to find out the right development policy. The purpose of this study is to look at the neo-endogenous model in rural development in the Koto Mesjid village and the efforts of the village government in shaping community characteristics in the neo-endogenous model. The study was conducted inKoto Mesjid village of Kampardistrictby using descriptive qualitative method and application of nvivo plus 12 to do the coding and qualitative dataanalysis. Results of the study are expectedto be development referenceof village development model that has the same modelused inthis study.

Kata Kunci : development, rural, neo-endogenous 


\section{PENDAHULUAN}

Pembangunan pedesaaan semakin menjadi pusat perhatian sejak dtetapkannya Undang-Undang Desa nomor 6 tahun 2014 tentang desa. Salah satu ukuran pembangunan yang digunakan adalah indeks pembangunan desa (IPD). IPD disusun untuk menilai tingkat kemajuan, perkembangan desa di Indonesia. Pengukuran IPD diperoleh dari Pendataan Potensi Desa (Podes) dan digunakan sebagai rujukan indikator-indikator utama penyusun indeks. IPD dapat digunakan untuk mengidentifikasi pembangunan desa yang menggambarkan ketersediaan dan aksesibilitas pelayanan kepada masyarakat desa. Ukuran pembangunan tersebut memudahkan pemerintah baik pusat maupun daerah untuk menetapkan dan memberikan prioritas dan seleksi pada upaya peningkatan pelayanan masyarakat terutama yang masih berada pada level rendah.

Perkembangan Indeks pembangunan desa di Provinsi Riau menggambarkan telah terjadi perbaikan dalam pembangunan. Hasil Pendataan Potensi Desa (Podes) tahun 2018 yang dilakukan Badan Pusat Statistik (BPS) setiap 10 tahun sekali menunjukkan bahwa 1.875 wilayah administrasi pemerintahan setingkat desa yang terdiri dari terdiri dari 1.607 desa dan 268 kelurahan mengalami peningkatan pembangunan. Hasil pengkategorian indeks pembangunan desa (IPD) menunjukan jumlah desa tertinggal ada 88 (5,48 persen), desa berkembang 1.405 (87,43 persen), dan desa mandiri 114 (7,09 persen) (Kementerian desa pembangunan daerah tertinggal dan transmigrasi, 2019). Desa tertinggal berkurang sebesar 202 desa bila dibandingkan tahun 2014. Sementara itu, Desa Mandiri bertambah sebesar 73 desa.

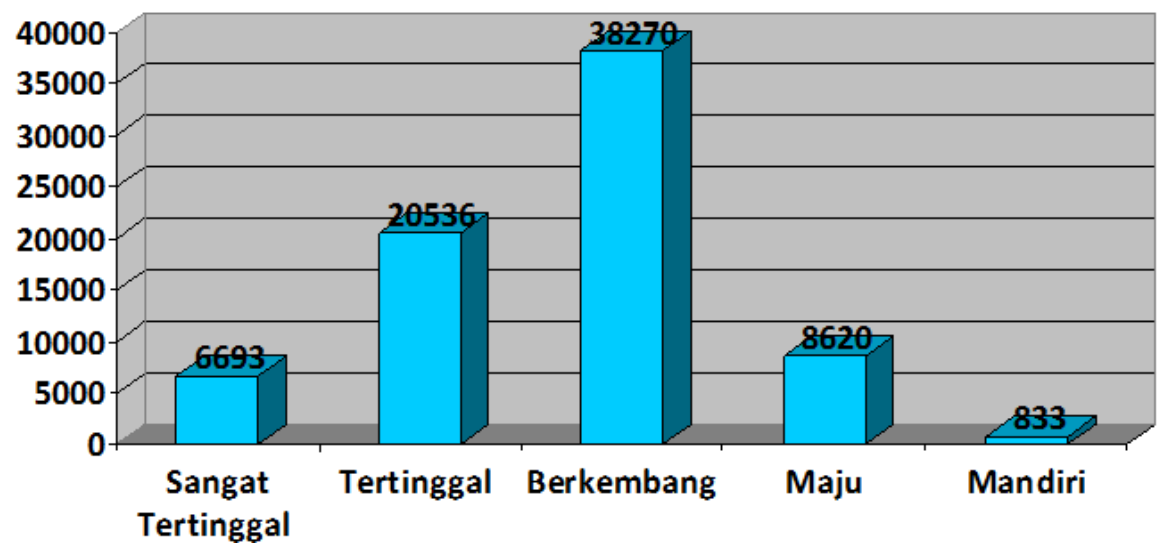

Grafik.1 Status Desa Tahun 2019

Indeks pembangunan desa mengukur perkembangan kemandirian Desa berdasarkan implementasi terhadap Undang-Undang Desa. Kemandirin desa penting dilakukan untuk mendorong pembangunan mandiri yang berfokus pada partisipasi masyarakat dan berkorelasi dengan karakteristik wilayah desa yaitu tipologi dan modal sosial. Berdasarkan Podes 2018, IPD Provinsi Riau pada tahun 2018 sebesar 63,54 meningkat 4,50 poin dibandingkan tahun 2014 sebesar 59,04. Artinya terjadi peningkatan kemandirian desa di Provinsi Riau. Data menunjukkan 87,43 persen desa di Riau adalah Desa Berkembang, 7,09 persen Desa Mandiri dan 5,48 persen adalah Desa tertinggal (Kementerian desa pembangunan daerah tertinggal dan transmigrasi, 2019) .

Ada berbagai model dalam melakukan pembangunan pedesaan untuk dapat mencapai kesejahteraan. Pendekatan yang menjelaskan bahwa penggerak dalam pembangunan di pedesaan diharapkan berasal dari masyarakat dan lingkungannya sendiri, tanpa campur tangan pihak luar (extra legal forces) yang dikenal sebagai pembangunan endogenous (Prabatmojo \& Argo, 2017). 
Pembangunan ini menitikberatkan pada identitas atau keunikan lokal yang menjadi sumbangsih bagi pembangunan perdesaan, dan masyarakat menjadi bagian terdepan memperkuat identitas perdesaan. Masyarakat lokal harus melakukan upaya pergerakan untuk dapat meningkatkan pembangunan desa.

Model yang mendekati kondisi dan karakteristik pada wilayah pedesaan di Indonesia adalah neoendogenous. Pembangunan neo-endogenous memungkinkan adanya peran extra local forces dalam pembangunan perdesaan, dimana posisi, potensi dan keberadaan dari extra local forces dapat digunakan bagi kepentingan di perdesaan itu sendiri (Prabatmojo \& Argo, 2017) . Pemerintah secara berjenjang melakukan upaya untuk meningkatkan status desa baik ditingkat desa, kecamatan, kabupaten, provinsi maupun pusat.

Salah satu desa yang diidentifikasi menerapkan model neo-endogenous dalam pembangunan pedesaan adalah desa Koto Mesjid. Desa Koto Mesjid adalah bagian wilayah administrasi kecamatan XIII Koto Kampar, Kabupaten Kampar, provinsi Riau. Desa Koto Mesjid dikenal juga sebagai Kampung Patin karena potensi lokal yang dikembangkan adalah perikanan khususnya ikan patin dengan 776 kolam ikan dan total luas kolam encapai 42 hektare. Selain itu desa Koto Mesjid juga telah melakukan pengolah ikan patin menjadi beberapa produk lainnya seperti salai (ikan asap), kerupuk, dan nugget. Selain itu, potensi lokal yang dikembangkan adalah pariwisata yang merupakan potensi lokal yang berasal sumber daya alam desa.

\section{METODE}

Penelitian Neo-Endogenous Model Dalam Pembangunan Pedesaan Di Desa Koto Mesjid, Kecamatan XIII Koto Kampar, Kabupaten Kampar dilaksanakan di Kabupaten Kampar, Provinsi Riau. Penelitian ini adalah penelitian deskriptif kualitatif dengan sumber data yang dibedakan menjadi dua, yaitu data primer dan data sekunder. Penelitian kualitatif dilakukan tanpa ada manipulasi peneliti dan kehadiran peneliti tidak mempengaruhi objek peneltian. Dalam menganalisis data dapat dilakukan bersamaan dengan pengamatan. Data yang diperoleh dapat langsung di analisis. Metode penelitian yang digunakan adalah adalah analisis deskriptif. Hasil wawancara dikodekan secara tematik kemudian dianalisis menggunakan perangkat lunak NVIVO 12 plus.

\section{HASIL DAN PEMBAHASAN}

\subsection{Neo-Endogenous Model}

Dalam pembangunan ada beberapa model yang dikenal untuk mengidentifikasi pembangunan. Pergeseran kebijakan pembangunan pedesaan dari exogenous model menjadi pendekatan endogenous model (Ward, N., Atterton, J., Kim, T.Y. Lowe, P., Phillipson, J., Thompson, 2005). Endogenous model mengemukaan lima hal yaitu prinsip utama, kekuatan dinamis, fungsi daaerah pedesaan, masalah utama pembangunan pedesaan, fokus pembangunan pedesaan. Sedangkan Neo Endegeneous Model memiliki enam indikator .Lima indikator tersebut adalah sebagai berikut berikut:

1. Prinsip utama dalam endogenus model adalah memanfaatkan sumber daya lokal dalam pembangunan berkelanjutan yang meliputi sumber daya alam, manusia dan budaya.

2. Kekuatan dinamis berasal dari inisiatif lokal dan perusahaan/swasta

3. Fungsi daaerah pedesaan ditujukan kepada beragam layanan ekonomi

4. masalah utama pembangunan pedesaan adalah terbatasnya kapasitas wilayah / kelompok untuk berpartisipasi dalam kegiatan ekonomi 
5. fokus pembangunan pedesaan adalah pembangunan kapasitas meliputi skil, kelembagaan dan infrastruktur; dan mengatasi pengecualian

Sedangkan neo-endogenous model memiliki enam indikator sebagai berikut:

1. Prinsip utama dalam neoendogenus model adalah keadilan sosial spasial dan menyeimbangkan kebutuhan lokal ketika bersaing untuk orang lokal, sumber daya, keterampilan dan modal

2. Kekuatan dinamis berasal Membina hubungan baru perkotaan-pedesaan dan lokal-global melalui pemerintahan yang inklusif, multi-skalar dan multi-sektoral pengaturan

3. Fungsi daaerah pedesaan ditujukan Mempertahankan mata pencaharian pedesaan, sambil mempertahankan modal alam; Mosaik fungsi produktif yang muncul kembali dan penggunaan konsumen (termasuk perumahan, layanan)

4. masalah utama pembangunan pedesaan adalah Pedesaan eksklusif; Deregulasi neoliberal versus apatis kebijakan dan kurangnya peraturan ; Tantangan perubahan iklim; Krisis ekonomi

5. fokus pembangunan pedesaan adalah Pembuatan tempat dan kesejahteraan masyarakat ; Membangun tempat-tempat pedesaan yang tangguh; Mengatasi politik penghematan yang baru; Mengatasi geografi pengecualian yang muncul dan immobilitas yang dipicu oleh krisis ekonomi; Menyadari dan menghargai alternatif pembangunan (Terutama non neoliberal) di masa krisis

6. Fokus penelitian pengembangan pedesaan yaitu Analisis komparatif, dialog, dan membagikan pelajaran/keilmuan kepada wilayah lainnya

Prabatmojo \& Argo menunjukkan bahwa Pembangunan Kawasan Perdesaan (PKP) Mandiri Pertanian yang mengutamakan pada pengintegrasian kebutuhan ruang untuk kegiatan sektoral di kecamatan Baros (Prabatmojo \& Argo, 2017). Namun, desa dengan administrasi yang kuat menunjukkan kecendrungan tidak memperdulikan desa lain disekitarnya tetapi desa dengan keterbatasan administrasi dalam pengelolaan pembangunan dan desa yang memiliki kepemimpinan fungsional cenderung menjaga identitas pertaniannya melalui kerjasama antar desa. Hal tersebut sedikit berbeda dengan Pembangunan desa di Koto mesjid sedang melakukan pengembangan di sektor perikanan bukan pertanian, serta berbeda dalam kerjasama dengan lintas sektor. Namun sebagian besar masyarakatnya bekerja disektor pertanian yaitu perkebunan karet.

Penelitian tersebut juga menunjukkan bahwa desa dengan status tertinggal, tidak dapat mengelakkan peran extra local forces yang diinisiatifkan pemerintah menjadi pemicu masyarakat untuk mendapat aliran informasi, pengetahuan, alih teknologi yang menyesuaikan pada kondisi lokal. Pembangunan neo-endogenous ini justru menjadi penggerak utama dalam membentuk masyarakat yang akan dipersiapkan untuk mandiri (Prabatmojo \& Argo, 2017). Masyarakat mampu memahami cara kerja pemerintah serta memanfaatkan kesempatan dari pemerintah dengan baik.

Penelitian lainnya yang dilakukan Astuti, dkk membandingkan antara konsep keahlian vernakular Phillip Lowe dengan keahlian vernakular pembangunan pedesaan yang terjadi di Indonesia. Hasil penelitian menunjukkan bahwa keahlian vernakular terutama dalam program Dana Desa tercermin dalam Musyawasarah perencanaan pembangunan desa (Musrenbangdes) yang melibatkan tokoh masyarakat, tokoh adat, tokoh agama, pemerintah desa, sektor swasta / bisnis, dan perwakilan daerah (RT, RW) dan representasi berbagai sektor ekonomi baik pertanian, kesehatan, pendidikan atau lingkungan (Astuti, Ahmad, \& Arsil, 2019). Musyawarah perencanaan pembangunan desa(Musrembangdes) yang baik yang harus melibatkan seluruh stakeholder. Keterlibatan satkeholder diharapkan dapat menyatukan arah dan pembangunan desa berdasarkan pengukuran potensi dan sumber pembangunan yang tersedia baik dari dalam maupun luar desa. 


\subsection{Keadilan spasial dan Keseimbangan Kebutuhan Lokal}

Amanat Undang-undang nomor 6 tahun 2014 tentang desa mengamanatkan bahwa pembangunan desa adalah upaya peningkatan kualitas hidup dan kehidupan untuk kesejahteraan masyarakat Desa ( Undang-Undang Desa , 2014). Namun tidak semua pembangunan yang diterapkan dapat mendorong peningkatan kualitas dan kesejahteraan masyarakat. Apabila dibandingkan dengan beberapa desa dalam Kecamatan XIII Koto Kampar, maka terlihat bahwa sejak diterapkannya undang-undang desa, desa Koto Mesjid telah berada pada status pembangunan desa berkembang sedangkan desa lainnya masih berada dalam kategori tertinggal dan sangat teringgal. Namun seiring perkembangannya, desa Koto Masjid mampu menjadi rule model /lesson learning bagi daerah sekitarnya. Hal ini dapat dilihat dari perkembangan status indeks desa membangun desa-desa tahun 2016 dan 2019 di Kecamatan XIII Koto Kampar.

Tabel 1. Status Pembangunan Desa di Kabupaten Kampar, Kecamatan XIII Koto Kampar Tahun 2016 dan 2019

\begin{tabular}{clcccc}
\hline No & Desa & \multicolumn{2}{c}{ Tahun 2016} & \multicolumn{2}{c}{ Tahun 2019} \\
& & Status & Indeks & Status & Indeks \\
\hline 1 & Balung & Sangat & 0,4290 & Tertinggal & 0,5506 \\
& & Tertinggal & & & \\
2 & Pulau Gadang & Tertinggal & 0,5234 & Berkembang & 0.6427 \\
3 & Tanjung Alai & Tertinggal & 0,5542 & Berkembang & 0.6478 \\
4 & Koto Tuo & Tertinggal & 0,5664 & Berkembang & 0.7054 \\
5 & Muara Takus & Sangat & 0,4676 & Berkembang & 0.6121 \\
& & Tertinggal & & & \\
6 & Gunung Bungsu & Tertinggal & 0,4915 & Berkembang & 0.6173 \\
7 & Koto Mesjid & Berkembang & 0,6055 & Maju & 0.7656 \\
8 & Lubuk Agung & Sangat & 0,4883 & Berkembang & 0.6554 \\
& & Tertinggal & & & \\
9 & Ranah Sungkai & Sangat & 0,4806 & Berkembang & 0.6381 \\
& & Tertinggal & & & \\
10 & Binamang & Tertinggal & 0,5053 & Berkembang & 0.6248 \\
11 & Pongkai Istiqamah & Tertinggal & 0,5522 & Berkembang & 0.6402 \\
12 & Koto Tuo Barat & Tertinggal & 0,4830 & Berkembang & 0.6592 \\
\hline
\end{tabular}

Sumber : Diolah dari Data Indeks Pembangunan Desa, Kemendesa 2019

Peraturan Menteri Desa, Pembangunan Daerah Tertinggal dan Trasnmigrasi Nomor 2 Tahun 2016 tentang Indeks desa membangun telah menetapkan batas/indek desa membangun dengan tujuan untuk menetapkan status kemajuan dan kemandirian desa serta untuk memberikan informasi dasar dalam pembangunan desa. Perbedaan perkembangan antara desa dalam kecamatan yang sama dapat disebabkan penerapan model pembangunan yang berbeda. Hal itu terlihat dari kondisi berbagai desa tersebut.

Salah satu prinsip utama dalam neo-endogenus model adalah keadilan spasial dan menyeimbangkan kebutuhan lokal ketika muncul persaingan untuk orang lokal, sumber daya, keterampilan dan modal. Model ini disatu sisi menguatkan peran internal tetapi tetap menganggap penting keterlibatan pihak luar. Keadilan yang dimaksud adalah terjamin pada keempat fungsi produksi seperti modal, tenaga kerja, sumber daya alam, dan keterampilan.

Sebelum diterapkannya budidaya patin, kepemilikan modal sempat mengalami kesulitan. Kondisi topografis Desa Koto mesjid yang memiliki karakteristik dataran tinggi, sulit air, dan mengandalkan air tadah hujan membuat masyarakat membutuhkan modal yang besar untuk memulai berbudidaya. Pada saat 
awal-awal pembudidayaan potensi lokal berupa ikan patin , masyarakat dan pemerintah mengalami kesulitan akses modal. Pada tahun 2000, ditemukan teknologi kejutan suhu dalam pembibitan komoditas ikan patin dan pembuatan pakan dengan sistem tradisional maka awal pembangunan mulai mengalami kesulitan modal karena operasional masyarakat untuk pembibitan dan pengelolaan ikan patin masih cukup tinggi dan belum ada mitra dari luar untuk pengembangan.

Tahun 2004, kerjasama sudah mulai dilakukan untuk mendrong akses modal yang dapat dijangkau masyarakat melalui program pinjaman lunak dari CSR Telkom. Namun perkembangannya saat ini kemudahan akses modal semakin baik. Perkembangan potensi desa di Koto mesjid baik dari segi pariwisata, sumberdaya alam maupun pengelolaan hulu hingga hilir produksi ikan patin menjadi daya tarik tersendiri bagi investor yang masuk. Dorongan dari Badan Usaha Milik Desa (BUMDes) juga memiliki peran dalam pemberian modal usaha khususnya pengembangan sektor perikanan tetapi juga perlu dikembangkan dalam kemudahaan akses pinjaman modal bagi sektor swasta yang saat ini sedang mengalami kemajuan.

Kebijakan publik yang dilaksanakan harus mampu menjamin keadilan dalam mengatur fungsi pembangunan sebab jika tidak, akan terjadi kegagalan keadilan berupa kesenjangan ekonomi yang tinggi serta ancaman ketidakberlanjutan (Sugiri, 2009). Akses kepada sumberdaya alam sebagai faktor produksi harus dapat adil dirasakan oleh seluruh masyarakat. Pada awal perkembangannya memang akses modal di desa Koto Mesjid mnengalami kesulitan karena belum ada kepercayaan akan keberhasilan usaha masyarakat. Sejak munculnya pelaku budidaya patin diawal pemberdayaan maka akses modal mulai dapat dirasakan tetapi pada kalangan terbatas. Namun seiring pendampingan dan pembinaan pelakupelaku budidaya dengan skala kecil juga mendapat kan akses modal dari investor.

Ketimpangan spasial tidak ditemukan dalam perencanaan pembangunan desa Koto Mesjid. Kegagalan keadilan dapat muncul jika hal-hal dibawah ini terjadi, diantaranya:

1. Jika akses modal hanya dapat diakses oleh aktor besar maka ini menjadi kegagalan keadilan (equity failure).

2. Persaingan yang tidak adil akibat perlakuan khusus oleh pemerintah yang hanya menguntungkan pelaku besar

3. Tersingkirnya para pelaku kecil yang mayoritas pada suatu wilaya pembangunan

4. Eksploitasi sumberdaya alam berlangsung pada tingkat yang sangat tinggi dapat mengancam keberlanjutan pembangunan.

5. Terjadinya eksternalitas negatif yang parah dari kegiatan ekonomi seperti polusi udara, air dan tanah yang merusak lingkungan

Faktor lainnya dalam melihat keadilan spasial adalah tenaga kerja. Dorongan terhadap tenaga kerja dapat dilihat dari meningkatnya jumlah pembudidaya ikan patin. Pekerjaan budidaya dan pengelolaan patin dianggap sebagai pekerjaan utama di desa Koto Mesjid. Kelompok umur didominasi oleh usia produktif yang berjumlah 821 jiwa atau 35,7 persen. Pemerintah dalam mendorong masayarakat dalam bekerja budidaya ikan kolam merupakan alternatif pertama masyarakat sebagai penganti mata pencaharian utama sebelumnya sebagai seorang petani karet. Fakta itu juga disebabkan oleh mata pencaharian masyarakat sebelum direlokasi sebagai transmigrasi lokal merupakan pencari ikan di sungai. 
Tabel 2. Pekerjaan Masyarakat Desa Koto Mesjid

\begin{tabular}{|l|l|l|}
\hline No & Pekerjaan & Jumlah \\
\hline 1 & Pembudidaya Ikan & 257 \\
\hline 2 & Pedagang & 167 \\
\hline 3 & Buruh & 129 \\
\hline 4 & PNS & 85 \\
\hline 5 & Petani Karet & 79 \\
\hline
\end{tabular}

Sumber : Pemerintah Desa Koto Mesjid, 2019

Pengembangan lainnya dapat dilihat dalam peningkatan keterampilan masyarakat. Pengembangan pariwisata baik pembinaan pemandu wisata, pengelolaan home stay dan penyajian kuliner di desa Koto Mesjid. Selain didorong oleh pemerintah desa dan swadaya masyarakat dalam mengembangkan keterampilan , masyarakat desa Koto mesjid juga bekerjasama dengan berbagai pihak seperti perguruan tinggi, maupun BUMN seperti SKK Migas - PT Chevron Pacific Indonesia (PT CPI). Pada tahun 2020, Dukungan tersebut dilakukan sberupa pelaksanaan program Pendampingan Desa Wisata Kampung Patin di Desa Koto Mesjid. Program ini merupakan pengembangan wisata berbasis komunitas (community based tourism/ CBT).

Selain itu, Tahun 2019 bekerja sama dengan Kementerian Pariwisata memberikan Pelatihan Masyarakat Desa Wisata di Kampung Patin Desa Koto Masjid Kecamatan XIII Koto Kampar . Pelatihan menghadirkan sekitar 50 orang. Dalam pelatihan ini masyarakat diberikan pemahaman tentang desa wisata dan membut sejumlah kue khas daerah Riau.

Persebaran pembangunan juga memperlihatkan keadilan spasial. Apakah pembangunan hanya terjadi di satu sisi atau wilayah saja misalnya hanya wilayah-wilayah dibagian utara sedangkan selatan tidak ada pembangunan atau hanya bagian barat sedangkan bagian timur wilayah tidak terperhatikan. Apabila melihat sebaran pembangunan sektor-sektor Publik di Desa Koto Mesjid masih berfokus di pusat pemerintahan. Hal ini dilakukan untuk memudahkan akses masyarakat terhadap fasilitas publik seperti lapangan olahraga, galeri / pusat sovenir desa, puskesmas, kantor desa, dan sekolah. Sedangkan wilayah yang belum dikembangkan sebagian besar berupa hutan yang ditumbuhi karet milik warga.

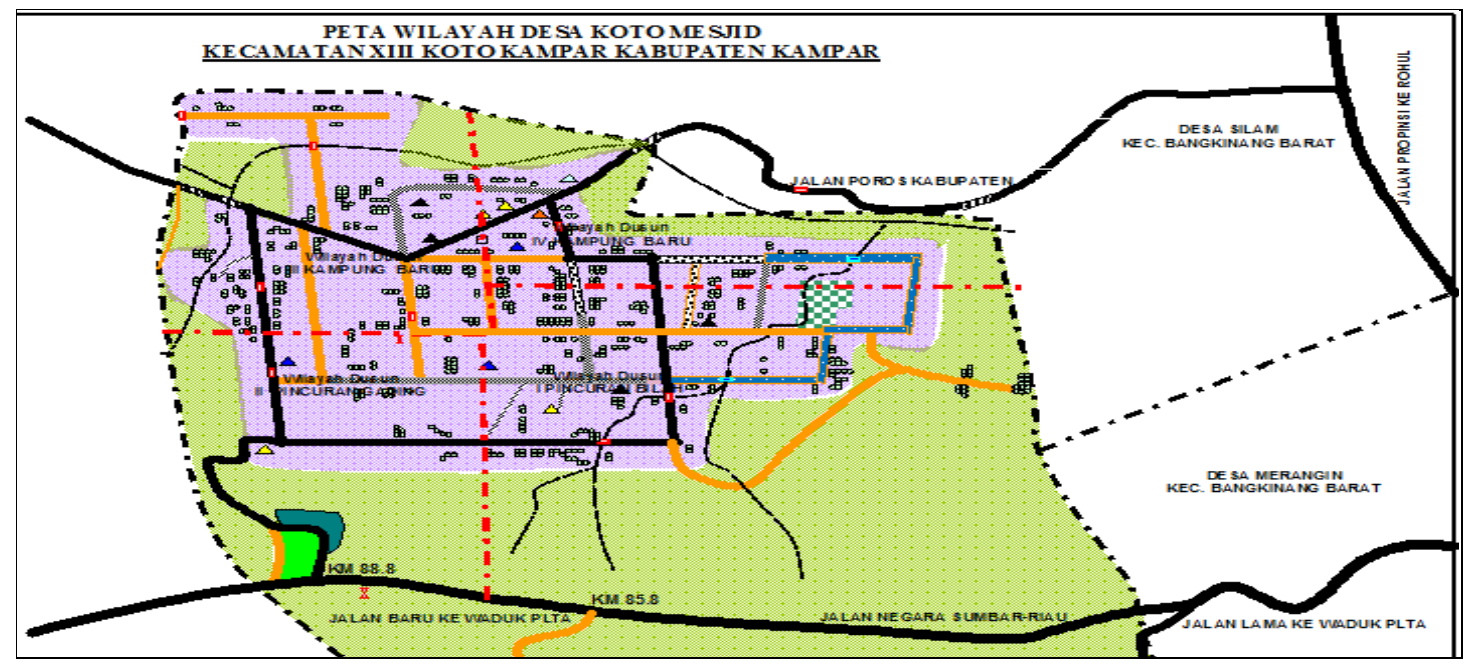

Sumber : Pemerintah Desa Koto Mesjid, 2020 


\section{KESIMPULAN}

Berdasarkan identifikasi terkait kebutuhan masyarakat lokal desa Koto mesjid di awal pembangunan menunjukkan bahwa masyarakat, pemerintah dan tokoh masyarakat telah mampu mengembangan potensi lokal dengan menerapkan budidaya ikan patin. Kesulitan akses modal diawal tidak menunjukkan bahwa terjadi ketidakadilan spasial dalam akses modal tetapi hal itu terjadi karena belum munculnya kepercayaan masyarakat dan investor diawal pembudidayaan. Namun seiring berjalannya pembinaan maka pembudidaya dapat mengakses modal baik dari investor maupun dari BUMDes Koto Mesjid. Perkembangan sumberdaya lokal berupa SDM sudah mulai mengembangkan sektor pariwisata, dukungan pemerintah maupun pihak eksternal sudah mulai dirasakan sebagai bentuk ciri-ciri neo-endogenous model.

\section{SARAN}

Perbedaan karakteristik suatu daerah harus di identifikasi dengan baik sehingga dapat diketahui bagaimana model pembangunan desa yang paling tepat untuk diterapkan. Hasil identifikasi model tersebut mampu menggambarkan kondisi pembangunan desa dengan tepat dan memudahkan untuk menemukan kebijakan apa yang telah membentuk model tersebut dan kebijakan apa yang dilakukan untuk meningkatkan pembangunan desa. 


\section{DAFTAR PUSTAKA}

[1]. Astuti, P. B., Ahmad, A. A., \& Arsil, P. (2019). Vernacular Expertise of Rural Development: An Exploratory Study In Indonesia. 5(1), 499-509.

[2]. Gkartzios, M., \& Lowe, P. (2019). Revisiting neo-endogenous rural development. (January). https://doi.org/10.4324/9781315102375-17

[3]. Kementerian desa pembangunan daerah tertinggal dan transmigrasi. (2019). Status IDM 2019.

[4]. Margarian, A. (2011). Endogenous Rural Development: Empowerment or Abandonment? 4th International Summer Conference in Regional Science, 1-34.

[5]. Petrick, M. (2013). Reversing the rural race to the bottom: An evolutionary model of neoendogenous rural development. European Review of Agricultural Economics, 40(4), 707-735. https://doi.org/10.1093/erae/jbt019

[6]. Prabatmojo, H., \& Argo, T. A. (2017). Mengawal Pembangunan Neo-Endogenous Di Perdesaan : Pengembangan Kawasan Perdesaan Di Kab Serang. 775-782.

[7]. Sugiyono. (2013). Metodelogi Penelitian Kuantitatif, Kualitatif Dan R\&D. Bandung: Alfabeta.

[8]. Sugiri, A dan Nuraini.2013. "Towards Equity based Regional Development: Addressing spatial inequality in the Blitar Region." The International Journal of Civic, Political, and Community Studies, 10 (3): 91-109.

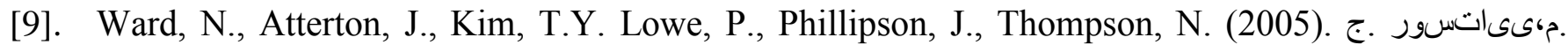

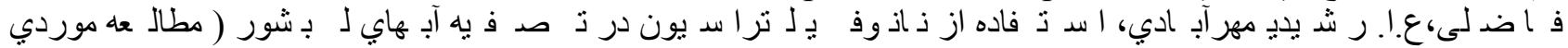

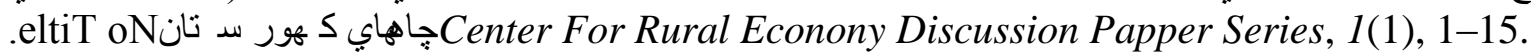

